\title{
WHAT DETERMINES THE PROFITABILITY OF COMPANIES: CASE OF CROATIAN FOOD AND BEVERAGE INDUSTRY
}

\author{
Maja Pervan ${ }^{a}$, Monika Mlikota ${ }^{b}$ \\ ${ }^{a}$ Associate Professor, PhD, Faculty of economics, University of Split, Cvite Fiskovića 5, Split, Croatia, mpervan@efst.hr. \\ ${ }^{b}$ Mag.oec, Faculty of economics, University of Split, Cvite Fiskovića 5, Split, Croatia, monika.mlikota@efst.hr.
}

\section{ARTICLE INFO}

Article data:

- Received: 19 January 2012

- Accepted: 13 September 2012

JEL classification: D22, D40, L25, C33

Keywords:

- Profitability

- Structure and firm specific factor

- Food and beverage industry

\section{ABSTRACT}

A company's profitability has always attracted the attention of academics and practitioners interested in revealing the main factors that determine business success. Although profitability has been widely investigated in manufacturing industry as a whole, studies related to the individual sectors within this industry are fairly rare. This is especially true for the food and beverage industry. Accordingly, the aim of this paper was to investigate the factors that determine companies' profitability in the Croatian food and beverage industry during the period from 1999 to 2009. The results of the conducted dynamic panel analysis revealed negative and significant influence of company's debt ratio on profitability; and significant positive influence of company's size, concentration ratio and past performance on current profitability. Additionally, MES, risk, and asset turnover had no significant role in determining profitability.

Reference to this paper should be made as follows: Pervan, M.; Mlikota, M. 2013.What Determines the Profitability of Companies: Case of Croatian Food And Beverage Industry, Ekonomska istraživanja Economic Research 26(1): 277-286. 


\section{INTRODUCTION}

Food and beverage industry is an important segment of every economy. According to the Croatian Chamber of Economy (CCE), food and beverage industry in 2009 participated with 21 percent in gross value added of Croatian manufacturing industry and employed about 47,000 people which is approximately 20 percent of the total employment in manufacturing industry. When compared with other segments of manufacturing industry, it can be stated that this industry employs the largest number of people and generates the highest value of total revenue. Unlike the other sectors of the Croatian economy that are stagnating or even declining over time, food and beverage industry has managed to maintain stability during the last decade. Accordingly, it is an area of strategic importance for the development of Croatian economy and society as a whole.

Taking into account that one of the main objectives of every company is profitability, it is obvious why determinants of companies' profitability have attracted the interest of academic research. In order to investigate the effects of firm-specific and industry-specific determinants on the firms' profitability we used dynamic panel data model and applied the GMM estimator proposed by Arellano and Bond (1991). The analysis was conducted for the period 1999-2009 and the results revealed that size, concentration and debt ratio have significant influence on company's profitability while minimum efficient scale, risk, and asset turnover had no significant role in determining profitability.

The paper will firstly present some of the main characteristics of Croatian food and beverage industry and then review the existing literature on determinants of firm's profitability. Subsequently it will discuss methodology and specification of variables as well as data source and the expected sign, followed by the results of the conducted analysis. The article concludes with the presentation of significant findings and a summary of the results.

\section{CHARACTERISTICS OF CROATIAN FOOD AND BEVERAGE INDUSTRY}

Food and beverage production is a very important activity for any country's economy, including Croatia. Each country tries (as far as possible independently) to meet the nutritional needs of its population with its own production and to minimize food import dependency. It was determined a long time ago that Croatia had significant natural, material and human resources as well as great potential for food production. This potential goes even above the level that meets the needs of its own population. ${ }^{1}$ The importance of food and beverage industry in Croatia is reflected in the size, growth and performance of this industry relative to the other sectors within Croatian economy.

Food and beverage industry involves companies that mainly belong to the most successful Croatian companies and in comparison to other manufacturing industries it is exactly this industry that achieves the highest total revenue and employs the largest number of people. ${ }^{2}$ According to the CCE, food and beverage industry participates with $18.63 \%$ in the total industry which means that it makes almost a fifth of the total industrial production, while its share in GDP is around $2.8 \%{ }^{3}$ Furthermore, the value of food and beverage industry in Croatia is reflected in the fact that its export structure is dominated by products of food industry, rather than primary

\footnotetext{
${ }^{1}$ Mirna Leko-Šimić, "Prehrambena industrija u istočnoj Hrvatskoj- karakteristike problemi i perspektive", in Strategija razvitka poljoprivrede i prehrambene industrije istočne Hrvatske, ed. by Marijan Jakšić (Osijek: Međunarodni znanstveno-stručni skup,Hrvatska gospodarska komora, 1999), 181-182.

${ }^{2}$ Dušan Tomašević, Strateški odzivi i performanse poduzeća u mesnoj industriji hrvatske (Magistarski rad, Split: Ekonomski fakultet 2007), 87.

${ }^{3}$ Statistical Yearbook of the Republic of Croatia 2010., Central Bureau of Statistics.
} 
agricultural produce. An additional characteristic of this industry making it important for the Croatian economy is its ownership structure which is still predominantly Croatian. All this makes the food and beverage industry, together with agriculture and tourism, one of the strategic sectors for the further development of Croatian economy.

\section{PREVIOUS RESEARCH}

Empirical researches that examine the impact of structural and firm-specific factors on the companies' performance were mainly conducted in the developed industrial countries, especially in the USA. Much less attention to this area was devoted in the less developed countries. ${ }^{4}$ Furthermore, researches related to the structural factors (such as, for example, different indicators of concentration, measures reflecting economies of scale and other measures reflecting barriers to entry) where implemented on a wide range of industries at an earlier stage, but later studies of this kind were mostly related to individual sectors (banking, agriculture etc). The results of these studies varied.

Most studies conducted at the industry level showed a positive relationship between concentration (as a commonly used indicator of market structure) and profitability, for example, Bain (1951) and Weiss (1974). After Weiss some experts expanded their studies to include other countries. Among them, Neumann and others (1979) studied western Germany; Bhattacharya and Bloch (1997) analysed Australia, Hsu et al. (2008) investigated Taiwan, Bhandari (2010) studied India, Harrison and Rude (2004) explored Canada, Resende (2007) investigated Brazil, etc. They also found a positive relationship between various indicators of market structure and profitability. However, Porter (1974), Connolly and Hirschey (1984) and Srinivas and Kumar (2010) came up with contradictory results based on the data from the USA and India. The above mentioned authors have shown that this relationship can also be negative or insignificant. Mixed results were also obtained in the various analyses that examined the impact of different firm specific factors and their influence on companies' profitability. Recent empirical studies based on the data from different countries include such authors like Vijayakumar (2011), Ito and Fukao (2010), Goddard et al. (2005), Hassan et al. (2011), Seelanatha, L., (2011),Nunes et al. (2010),Fenny at al. (2005) and so on. There is little literature that deals with structural and firm-specific factors and their influence on companies' profitability at the level of developing countries (Hsu et al. (2008), Chang-Yang and Mahmood (2009),Ponikvar and Tajnikar (2011)), while only few studies deals with the food industry Vlacllvci an Oustapassidis (1998), Stiegert et al. (2009), Juhász, et al. (2008), Ahmad and Shamsudin (2008).

Studies of this kind are non existent for the Croatian food and beverage industry. Therefore, in order to contribute to the understanding of the determinants of profitability of companies operating in developing countries and to shed new insights on the factors that may influence on business success, in this study a model of profitability that incorporates the structural and firm specific factors is formulated and tested.

\section{MODEL SPECIFICATION AND VARIABLES}

In order to investigate the way in which the profitability of the company is responding to structural changes and changes of other firm-specific factors, we constructed the profitability model in which we included different variables that are chosen on the basis of relevant theory and literature. In addition to theoretical considerations the choice of explanatory variables is

${ }^{4}$ Gurvinder S.Shergill and Maninder S. Sarkaria. "Market Structure and Financial Performance - An Indian Evidence With Enhanced Controls", The Indian Economic Journal 48, no. 2 (2011): 99. 
based upon the availability of data. As the starting point, we formed the database by consolidating data derived from the basic financial statements ${ }^{5}$ of each company operating in food and beverage industry in Croatia during the period from 1999 to 2009. Due to the lack of data (i.e. financial statements for the reference period) some companies could not be taken into consideration.

Regarding the statement that many of economic relations are dynamic in their nature and that past companies' performance may affect its future output decisions, a dynamic model (1) was estimated. This dynamic model uses GMM estimator proposed by Arellano and Bond (1991).

The general model estimated in our analysis can be presented as:

$$
\pi_{\mathrm{it}}=\alpha+\delta \pi_{\mathrm{i}, \mathrm{t}-1}+\sum_{f=1}^{F} \beta_{f} \mathrm{X}_{\mathrm{it}}^{f}+\sum_{s=1}^{S} \beta_{s} \mathrm{X}_{\mathrm{it}}^{s}+\varepsilon_{\mathrm{it}}
$$

where $\pi_{\mathrm{it}}$ represents the profitability of a company $i$ at time $t$, with $i=1, \ldots, N, t=1, . ., T$; ais a constant term, $\pi_{i, t-1}$ is the one-period lagged profitability, $\delta$ isthe speed of adjustment to equilibrium, $\mathrm{X}_{\mathrm{it}}^{\prime}$ 's are the explanatory variables (namely, $\mathrm{X}_{\mathrm{it}}^{\mathrm{f}}$ denotes firm-specific variables; $\mathrm{X}_{\mathrm{it}}^{\mathrm{s}}$ denotes structure i.e. industry-specific variables), $\varepsilon_{\mathrm{it}}$ is the disturbance, with $v_{\mathrm{i}}$ the unobserved firm-specific effect and $u_{i t}$ the idiosyncratic error.

As a dependent variable reflecting companies' profitability, we employ EBITDA ratio. EBITDA was calculated as a sum of profit after taxes, cost of interest, income taxes and depreciation and the resulting value was divided by sales revenue.

The independent variables included in the model are industry concentration and the minimum efficient size of a plant (i.e. industry-specific variables), size of the company, debt ratio and asset turnover ratio (i.e. firm-specific variables). Risk is introduced in the model as a control variable.

Most studies trying to explain relationship between market structure and companies' profitability use measuresof concentration (concentration ratio - CR and/or HerfindahlHirschman index - $\mathrm{HHI}$ ) as an approximation of industry structure because these parameters tend to embrace number and size distribution of companies within the industry. Taking into account the above, concentration ratio of three leading companies in the industry $\left(\mathrm{CR}_{3}\right)$ and Herfindahl-Hirschman index $(\mathrm{HHI})$ was calculated (at the three digit level of NACE) and as a basis for calculation of these measures, sales revenue was used. ${ }^{6}$

Barriers to entry are those factors which allow established firms on the market to charge higher than competitive price and thus to achieve higher than competitive profits. Technology, as one of the factors that determine barriers to entry, often occurs in the form of minimum efficient scale - MES. It represents the size of the company at which long-run average costs are at the minimum. If an industry has a very large MES this may discourage new companies from entering the market and therefore it can be expected that the $\mathrm{MES}^{7}$ will have positive impact on

\footnotetext{
${ }^{5}$ Basic financial statements used in this case are the balance sheet and income statement (profit and loss statement). Until 2007 these statements were obtained from the Financial Agency (FINA), while for 2008 and 2009 data were downloaded from the FINA web site http://www.fina.hr/Default.aspx

${ }^{6} \mathrm{HHI}$ index has been calculated on the basis of market shares of large and medium-sized companies and other companies in the industry are assumed to have equal market shares.

${ }^{7}$ Simon Feeny, Mark N. Harris, and Mark Rogers, "A dynamic panel analysis of the profitability of Australian tax entities." Empirical Economics 30, no.1 (2005): 214.
} 
profitability. In this study MES was calculated as an average value of assets of companies controlling $50 \%$ of the revenue at the three digit level of NACE.

Firm size (SIZE) is one of the variables that reflect firm-specific factors. Variable such as firm size might be important since it can be the source of economies and diseconomies of scale. ${ }^{8}$ In this study, SIZEvariable is measured as the natural logarithm of the total assets of the company. Firm size can have a positive impact on profits in a manner that it can behave as a barrier to entry. Otherwise, if there is a negative relationship between profitability and assets, that implies an inefficient use of assets. Since previous researches show the presence of positive as well as negative impact of this variable on the profitability of the company, this study does not prejudice a priori a sign that the SIZE variable would have to take.

Debtof a company is the next variable that can have a significant influence on the profitability of the company. Debt ratio, calculated as the ratio of total liabilities to total assets, shows how much of companies' assets was funded by outside sources. This indicator shows the ability of the company to cover all its obligations to its creditors and investors. The higher the degree of debt the higher the risk of business, and it should not be greater than $50 \%{ }^{9}$ The higher the degree of indebtedness, the greater amount of debt is used to generate the profit. Researches associated with the impact of debt on return of a company have also led to different results. ${ }^{10}$

Asset turnover may also have impact on the profitability of the company. Analysis of the relationship between income and assets is known as analysis of turnover of total assets. This coefficient is used to measure how many units of income come from one unit of assets of the company. Therefore, asset turnover ratio is used to measure the effectiveness of the operations. A high asset turnover ratio is preferable to the lower because the former is an indicator of the better operating performance. Additionally, a higher asset turnover ratio symbolizes greater shareholder wealth. However, an inverse relationship exists between profit margin and asset turnover ratio. For example, if the net profit margin is high, revenue or net sales will thus be low and this will result in lower asset turnover ratio.

We use risk variable as a control variable in the model. In industry research in USA, variance of individual rates of return is used as an index of risk. ${ }^{11}$ According to the traditional theory that relates risk and rates of return, most stockholders tend to avoid risk and in order to take the higher risk they require a higher return ("risk premium") as a reward for taking on more risk. Thus, according to the "risk premium hypothesis" the risk and rate of return should be positively correlated.

\section{RESULTS OF EMPIRICAL RESEARCH - DYNAMIC PANEL ANALYSIS}

This analysis was conducted on the sample of medium and large Croatian companies that operated within the food and beverage industry during the period from 1999 to 2009. Companies whose data were not available during the period covered by this analysis as well as companies that were making losses and/or were in process of bankruptcy were excluded from the analysis.

\footnotetext{
${ }^{8}$ David Besanko and Ronald R. Braeutigam, Microeconomics (Hoboken: John Willey \& Sons, 2011): 231.

${ }^{9}$ Vinko Belak, Menadžersko računovodstvo (Zagreb: RRiF plus: 1995).

${ }^{10}$ Matarirano Obert and Fatoki Olawale, "Does debt really matter on the profitability of small firms? A perspective on small manufacturing firms in Bulawayo, Zimbabwe", African Journal of Business Management 4,no. 9 (2010):1709.

${ }^{11}$ Manfred, Neumann, Ingo Böbel, and Alfred Haid, "Profitability, Risk and Market Structure in West German Industries", The Journal of Industrial Economics 27, no. 3 (1979): 227.
} 
Taking this into consideration, the total number of observations for all the selected industries in the observed period was 1059 .

In order to estimate the earlier presented model of companies' profitability (1) GMM Arelano Bond estimator was applied. The first step in the model estimation was to test the validity of the instruments that were taken into consideration. Validity of instruments in the model was tested by using Sargan test. The value of Sargan test for over identification of the restrictions should be higher than 0.05 in order to exclude the possibility of exogenous instrumental variables. Namely, the optimal number of instruments must be selected in order that null hypothesis of Sargan test can be true without significant increase of bias estimator. ${ }^{12}$

TABLE 1 -RESULTS OF ESTIMATION OF DYNAMIC PANEL MODEL

\begin{tabular}{ccc}
\hline \hline \multicolumn{1}{l}{ Variables } & Coefficient & $\mathrm{P}$ \\
\hline \hline EBITDA $_{\mathrm{t}-1}$ & 0.0913527 & 0.017 \\
SIZE & 3.801991 & 0.059 \\
$\mathrm{CR}_{3}$ & 0.092698 & 0.083 \\
MES & -0.000001 & 0.332 \\
RISK & 0.000866 & 0.837 \\
DEBT & -0.135329 & 0.001 \\
ASSET TURNOVER & -1.563447 & 0.220 \\
Constant & -0.536151 & 0.015 \\
\hline Sargan test & & \\
(p-value) & & \\
Arelano Bond (m1) & & \\
(p-value) & & \\
Arelano Bond (m1) & & \\
(p-value) & & \\
\hline \hline Authors' calculation & & \\
\hline
\end{tabular}

The Table 1 indicates that there isno evidence of over-identifying restrictions because the value of Sargan test is 0.5512 . In this case the null hypothesis (the selected instrumental variables are uncorrelated with the residuals) is not rejected, meaning that all conditions for the moment are satisfied and that all instruments in the model are accepted. Besides Sargan test two more tests where conducted. ${ }^{13}$ These are first-order and second-order tests of autocorrelation of the first differenced residuals (tests $m_{1}$ and $m_{2}$ ). Neither one of these tests does not reject hypothesis of no autocorrelation of the first or second order (statistically insignificant p-value). According to all the performed tests it can be concluded that the estimated model satisfies all the diagnostic tests.

\footnotetext{
${ }^{12}$ A.C. Cameron and Trivedi P.K., Microeconometrics Using Stata (Revised Edition, A Stata Press Publication. Texas: StataCorp LP, College Station, 2010): 301.

${ }^{13} \mathrm{~T}$.W. Anderson and Cheng Hsiao, "Estimation of Dynamic Models with Error Components," Journal of the American Statistical Association 76, no. 375 (1981): 598.
} 
The estimated parameter of the independent lagged variable $\left(E B / T D A_{t-1}\right)$ shows that profitability of the company (within the food and beverage industry) from the previous period has positive and statistically significant influence on companies' profitability in the current year. This confirms the dynamic character of the model. Taking into account the interval of parameter $\delta$, and watching the value of this parameter in model 1 which is closer to 0 than to 1 (i.e. 0.0913527), it is possible to conclude that this is a relatively competitive industry. This indicates the high speed of adjustment of profits to those in equilibrium. Concentration (approximated with $\mathrm{CR}_{3}$ index) also shows positive and statistically significant influence on the profitability of a company. Having in mind the assumptions of the SCP theory according to which firms operating in a concentrated industry are likely to benefit from collusion, higher prices and therefore profits, it can be concluded that SCP theory is true in case of Croatian food and beverage industry. Almost identical values (in terms of statistical significance and strength/intensity of effect) are obtained when we introduce variable $\mathrm{HHI}$ as a variable of concentration instead of $\mathrm{CR}_{3}$. Positive and statistically significant influence of variable SIZE on companies' profitability indicates the existence of economies of scale in food and beverage industry in Croatia. Considering this, large companies have advantage in comparison to small companies because they have lower operating costs as well as lower cost of production and also stronger bargaining power towards suppliers and distributors. Another variable in the estimated model has a statistically significant impact on the profitability of companies in food and beverage industry, and this is the debt variable. The negative sign of this variable indicates that a fall of enterprise profitability will occur if the ratio between total liabilities and total assets of a company increases. Expressed in terms of profitability of companies operating in the food and beverage industry, one might conclude that a high level of debt due to high interest payments and consequently increased enterprise risk, is leading to poor business results and to poor profitability. MES (representing barrier to entry) is not a statistically significant variable, meaning that in the Croatian food and beverage industry there are no indications of the existence of obstacles, expressed in terms of minimum efficient plant size that would discourage new companies to enter the industry. This is supported by the fact that during the period covered by this analysis the number of companies increased by almost $40 \%$. Finally, with regards to statistical insignificance of the variables risk and assets turnover it can be concluded that these variables do not play a significant role in achieving the profitability of companies in Croatian food and beverage industry.

\section{CONCLUSION}

Food and beverage industry is one of the strategically important sectors for the development of Croatian economy. This industry is among the few industries in Croatia that have managed to survive over time, have contributed to the total industrial production and are above all particularly successful. This industry is certainly significant in terms of production facilities, income that it generates and the number of employees in it. Structure of the food and beverage industry is dominated by a small group of large companies that occupy the largest share when we take into account employment and total income.

Food and beverage industry has undergone numerous changes in the period from 1999 to 2009. Many trends in surroundings have influenced the development of this industry. To analyze and investigate the structural and firm-specific factors that determine the success of a company we used dynamic panel analysis and applied the GMM estimator proposed by Arellano and Bond (1991). The research has shown that profitability of a company from the previous period (in this case observed over EBITDA indicator) has a statistically significant influence on profitability in the current period. Small value of this parameter indicates that profitability of competing firms is not persistent and that differences in profits among firms will disappear in the long run. Therefore 
Croatian food and beverage industry can be described as a relatively competitive industry.Further, the study results indicated the existence of a positive relationship between industrial concentration and profitability of enterprises (assumptions of SCP paradigm are valid), which means that in industries characterized by high concentration companies are approaching to anti-competitive behaviour (i.e. collusion among large firms in the industry is present) which in turn weakness the market competition and ultimately leads to increase of profits. However, due to insignificant influence of barriers to entry in to the company's profitability, the results indicate that Croatian food and beverage industry is not protected by entry barriers that would prevent the entry of new firms into the market and thus further ensure high profits to the existing firms in the market. In addition to studying the influence of market structure on company profitability we also studied the impact of firm-specific factors on it. The results of the estimated model of profitability of a company show that asset turnover ratio has no statistical significance on profitability as opposed to the size and debt ratio. A negative sign of debt ratio variable indicates that a high level of debt due to high interest payments (and consequently increased enterprise risk) is leading to poor business results and to poor profitability. On the other side, a positive influence of a firm's size on its profitability may be due to the fact that large firms are more efficient on account of scale economies. Also, large firms may have more capital or favorable financing conditions i.e. small firms often suffer from borrowing constraints. Furthermore, large firms may use their reputation as an advantage or may have an advantage in negotiations with suppliers and channel members. Finally, large firms may have more market power that enables them to profitably raise the market price and consequently earn higher profits.

\section{REFERENCES}

Ahmad, Tengku M.A.T., and Mad N. Shamsudin. Market liberalization and its relationship with market structure, conduct and performance of the food processing industry in ASEAN economies, Malaysian Agricultural Research \& Development Institute, 2008.

Anderson, T.W., and Cheng Hsiao. "Estimation of Dynamic Models with Error Components," Journal of the American Statistical Association 76, no. 375 (1981): 598-606.

Arellano, Manuel and Bond Stephen. "Some Test of Specification for Panel Data, Monte Carlo Evidence and Application to Employment Equations", Review of Economic Studies 58, (1991): $277-297$.

Bain, Joe S. "Relation of profit rate to industry concentration", Quarterly Journal of economics65, no. 3 (1951): 293-324.

Belak, Vinko.Menadžersko računovodstvo. Zagreb: RRiF plus: 1995.

Besanko, David, and Ronald R. Braeutigam. Microeconomics. Hoboken: John Willey \& Sons, 2011.

Bhandari, Anup K. "Concentration, Entry Barriers and Profitability in the Indian Industries: An Empirical Analysis",Journal of Quantitative Economics 8, no. 2 (2010): 61-80.

Bhattacharya, Mita and Harry Bloch. "Specification and Testing the Profit-Concentration Relationship in Australian Manufacturing", Review of Industrial Organization12, no. 2 (1997): 219-230.

Cameron, Collin A., and Trivedi,Pravin K.Microeconometrics Using Stata. Revised Edition, A Stata Press Publication. Texas: StataCorp LP, College Station, 2010.

Chang-Yang, Lee, andIshtiaq P.Mahmood."Inter-industry differences in profitability: the legacy of the structure-efficiency debate revisited", Industrial \& Corporate Change 18, no. 3 (2009): 351-380. 
Connolly, Robert A., and Mark Hirscher. "R\&D, Market structure and Profits: A value- based approach", Review of economics and statistics 66, no.4 (1984): 682-86.

Feeny, Simon, Mark N. Harris, and Mark Rogers."A dynamic panel analysis of the profitability of Australian tax entities." Empirical Economics 30, no.1 (2005): 209-233.

Financial Agency (FINA),http://www.fina.hr/Default.aspx (accessed, 10-20 January, 2011)

Goddard, John, Manouche Tavakoli, and John O.S. Wilson. "Determinants of Profitability in European Manufacturing and Services: Evidence from a Dynamic Panel Model",Applied Financial Economics 15, no. 18 (2005):1269-82.

Harrison, Darryl, and James Rude. "Measuring industry concentration in Canada's food processing sectors", Agriculture and Rural Working Paper Series, no. 70 (2004).

Hassan, Muhammed, and Muhammad Rizwan Salem S. "Organizational Determinants of Firm Performance: A Case of Garments Manufacturing Firms of Lahore, Pakistan"International Journal of Research in Commerce and Management 2, no. 11 (2011): 38-42.

Hsu, Song-Ken, and Ming-Fang Tsai, Chih-Hai Yang. "Market Structure, External Exposure and Industry Profitability: Evidence from Taiwan",International Economic Journal 22, no. 2 (2008): 201-214.

Ito, Keiko, and Kyoji Fukao. "Determinants of the Profitability of Japanese Manufacturing Affiliates in China and Other Regions: Does Localisation of Procurement, Sales and Management Matter?",World Economy 33, no. 12 (2010):1639-1671.

Juhász, Aniko, Antal Seres, and Marta Stauder. "Business concentration in the Hungarian food retail market", Studies in Agricultural Economics, no. 108, (2008): 67-80.

Leko-Šimić, Mirna. "Prehrambena industrija u istočnoj Hrvatskoj- karakteristike problemi i perspektive". In Strategija razvitka poljoprivrede i prehrambene industrije istočne Hrvatske, edited by Marijan Jakšić et al., 181-188. Osijek: Međunarodni znanstveno-stručni skup,Hrvatska gospodarska komora, 1999.

Neumann,Manfred, Ingo Böbel, and Alfred Haid. "Profitability, Risk and Market Structure in West German Industries", The Journal of Industrial Economics 27, no. 3 (1979): 227-242.

Nunes, Paulo M., Zelia S. Serrasqueiro, and Joao Leitao."Are there nonlinear relationships between the profitability of Portuguese service SME and its specific determinants"Service Industries Journal 30, no. 8 (2010): 1313-1341.

Obert, Matarirano and Fatoki Olawale. "Does debt really matter on the profitability of small firms? A perspective on small manufacturing firms in Bulawayo, Zimbabwe",African Journal of Business Management 4,no. 9 (2010): 1709-1716.

Državni zavod za statistiku RH, Osnovni strukturno-poslovni pokazatelji poduzeća u 2009, Priopćenje,http://www.dzs.hr/Hrv_Eng/publication/2010/15-01-03_01_2010.htm (accessedMay 18, 2011).

Ponikvar, Nina, and Maks Tajnikar. "Are the determinants of markup size industry-specific? The case of Slovenian manufacturing firms", Panoeconomicus, no. 2, (2011): 229-244.

Porter, Michael E. "Consumer Behavior, Retailer Power and Performance in Consumer Goods Industries", The Review of Economics and Statistics, 56, (1974): 419-436.

Resende, Marcelo. "Structure, conduct and performance: a simultaneous equations investigation for the Brazilian manufacturing industry", Applied Economics 39, no.7 (2007): 937-942.

Seelanatha, Lalith. "Determinants of Firms' Performance: Some Chinese Evidence", Investment Management and Financial Innovations 8, no. 3 (2011): 28-38.

Shergill, Gurvinder S. and Maninder S. Sarkaria. "Market Structure And Financial Performance - An Indian Evidence With Enhanced Controls", The Indian Economic Journal 48, no. 2 (2011): 97-107. 
Srinivas, C., and Sushil Kumar. "Is Structure-Conduct-Performance a case of structureperformance?: Structural Equation Modelling of Indian industries", International Journal of Business and Emerging Markets 2, no.1 (2010): 3 - 22.

Statistical Yearbook of the Republic of Croatia 2010., Central Bureau of Statistics.

Stiegert, Kyle W., Shinn-Shyr Wang and Richard T. Rogers. "Structural Change and Market Power in the U.S. Food Manufacturing Sector", Agribusiness 25, no.2 (2009): 164-180.

Tomašević, Dušan.Strateški odzivi i performanse poduzeća u mesnoj industriji hrvatske, Magistarski rad, Split: Ekonomski fakultet, 2007.

Vijayakumar, A."The Determinants of Profitability: An Empirical Investigation Using Indian Automobile Industry", International Journal of Research in Commerce and Management 2, no. 9 (2011): 58-64.

Vlacllvci, Aspassia and Konstantinos Oustapassidis."Advertising, Concentration and Profitability in Greek Food Manufacturing Industries", Jurnal of Agricultural Economics 18 (1998): 195-198.

Weiss, Leonard W. "The concentration-profits relationship and antitrust". In Industrial concentration: The new learning, edited by Harvey J. Goldschmid et al.Boston: Little, Brown and Company, MA, 1974.

\section{ŠTO ODREĐUJE PROFITABILNOST PODUZEĆA: SLUČAJ INDUSTRIJE HRANE I PIĆA U HRVATSKO]}

Sažetak: Profitabilnost poduzeća je oduvijek privlačila pozornost brojnih znanstvenika i stručnjaka usmjerenih prema istraživanju glavnih faktora koji određuju poslovni uspjeh poduzeća. lako je profitabilnost naširoko istraživana u prerađivačkoj industriji kao cjelini, studije vezane za pojedine sektore unutar ove industrije su iznimno rijetke. Ovo posebice vrijedi za industriju hrane i pića. Sukladno tome, cilj ovog rada bio je istražiti faktore koji determiniraju profitabilnost poduzeća koja su djelovala u hrvatskoj industriji hrane i pića tijekom vremenskog perioda od 1999 do 2009. Rezultati dinamičke panel analize otkrivaju negativan i statistički značajan utjecaj zaduženosti poduzeća na njegovu profitabilnost, te statistički značajan pozitivan utjecaj veličine poduzeća, industrijske koncentracije i uspješnost poslovanja iz prethodnog razdoblja na profitabilnost u tekućoj godini. Dodatno, rezultati istraživanja su pokazali kako MES, rizik i obrtaj imovine nemaju značajnu ulogu u određivanju profitabilnosti poduzeća.

Ključne riječi: profitabilnost, strukturi i poduzeću specifični faktori, industrija hrane i pića 